\title{
Recent Trends of Foreign Direct Investment in India: A Review
}

\author{
Deepak Kumar ${ }^{1}$, Dr. S. Srinivas Rao ${ }^{2}$, Ms. Shweta Shriwas ${ }^{3}$ \\ Department of Management studies ${ }^{1}$, MSMSR $^{2}$, Department of Management studies ${ }^{3,}$, MATS University ${ }^{2}$, LCIT $^{2}$ \\ Group of Institution, \\ Email:deepakkumar.incometax@gmail.com ${ }^{1}$,drsrao@matsuniversity.ac.in.2 ,'shweta.shrivas0914@gmail.com
}

\begin{abstract}
Nations desiring for sustainable economic growth has to explore global opportunities and FDI (Foreign Direct Investment) helps in achieving significant development for the economy. FDI is considered to be the most essential medium of development in the emerging sectors of an economy. India is an emerging market globally due to its various prospering aspects like cheap labour, greater market size and abundance natural resources etc. which attract foreign investors for better prospects in various sectors. The present paper aims to study the trends of FDI in the country and understand the reason behinds its fluctuations. This study was conducted to investigate the trends of FDI in India and to find out the impact of Make in India policy on FDI. The study also aimed to understand the role of FDI for the development of a nation. It was found that India succeeded in attracting foreign investors after the launching of Make in India policy and various other government reforms. In India, various sectors are emerging, for example - tourism, transport, communication, health and education. These sectors desperately require FDI for its prosperity and development. Besides, FDI is also an ideal solution for socio-economic problems like unemployment, deficit BOP (Balance of Payment), technological incapability and lack of sufficient foreign exchange. To get the desired level of economic growth, the best outcome comes in the form of FDI where a developed country invests through its capital and latest technology in a developing nation and explores its natural and human resources.
\end{abstract}

Index Terms- FDI, Liberalization, Investment, Economic Growth, Export and Import, Make in India

\section{INTRODUCTION}

Foreign Direct Investment (FDI) is a fund flow between the countries in the form of inflow or outflow by which one can be able to gain some benefits from their investment whereas another can exploit the opportunity to enhance the productivity and find out better position through performance. (Saini, 2010). Broadly, there are two types of FDI. One is Inward Foreign Direct Investment (IFDI) which means such foreign investors who invests in the local goods of the economy and the other is Outward Foreign Direct Investment (OFDI) which means when an investor from the economy expands the operation of their firm into another foreign country. On one hand, IFDI injects money in the economy from external sources whereas OFDI launches its goods globally through mergers and acquisition. (Singh, 2011)

FDI can be beneficial to a business establishing from the scratch to the business interested in expanding its existing business through mergers and acquisition. It usually involves management control, interference / participation in managerial activities, capital \& technology transfers (Agrawal, 2011)

FDI plays a vital role in filling up the gap between the domestic investments and savings by injecting surplus funding to the domestic firm and multiplying the opportunities for employment, expansion, revenue and emerging international markets. FDI bringing inflow are found to be more attractive because the investing firm brings their latest techniques, machineries and equipments from outside in the host country to reduce the cost of production which finally results in significant increase in the exports of the domestic firms (Arindam, 2004).

The effectiveness and efficiency depend upon the investors' perception, if investment with the purpose of long term then it contributes positively towards economy and on the other hand if it is for short term for the purpose of making profit then it may be less significant.(Andreas, 2004). Depending on the industry sector and type of business, a foreign direct investment may be an attractive and viable option. Any decision on investing is thus a combination of an assessment of internal resources, competitiveness market analysis and market expectations.

FDI builds up a healthy atmosphere for the skilled workforce and helps in substituting the foreign latest technology with local outdated technology (Nair ,2010). Depending upon the categories of industries, the RBI permits the level of equity up to $24 \%, 50 \%$, $51 \%, 74 \%$ and $100 \%$ (Singh, 2014).

Various forms of FDI are FDI in the industries, foreign collaboration, loans between inter-government or loans from a institutions and other commercial borrowing (Singh, 2014). 


\section{E-ISSN: 2321-9637 \\ Available online at www.ijrat.org}

\section{CONTRIBUTION OF THE STUDY}

For the growth of any economy, it is important for them to explore global opportunities and participate in cross nations trades. FDI (Foreign Direct Investment) provides this facility by inviting the foreign investors around the world inducing their wealth into a nation and by utilizing these; investment wealth creation is attained at the desired level. FDI bring a common platform for the world economy to achieve mutual benefits. The study emphasizes on FDI in India after 1991, their major sources, emerging sectors for investments and also studies the impact of Make in India policy on FDI. The research is also going to study the role of government policies for promoting export and import of the nation.

\section{OBJECTIVES OF THE STUDY}

- To study the recent trends of FDI inflows in India

- To evaluate the impact of FDI on the Indian Economy

\section{LITERATURE REVIEW}

Cherian, Iyare Sunday O, Bhaumik Pradip K, Banik Arindam (2004) in their work "Explaining FDI Inflows to India, China and the Caribbean: An Extended Neighborhood Approach" found out that the FDI flows are generally believed to be influenced by economic indicators like market size, export intensity, institutions, etc, irrespective of the source and destination countries.

John Andreas (2004) in his work "The Effects of FDI Inflows on Host Country Economic Growth" discussed the potential of FDI inflows to affect the economic growth of the host country.

Singh S., Singh M. (2011), "Trends and prospects of FDI in India" in his study investigated the trend of FDI inflow to India during 1970-2007 using time series data. This paper aims to study the reasons behind the fluctuations of the FDI in flow in India and to search the cause that is responsible for the fluctuations of the trends of FDI.

Agarwal G., Khan M. A. (2011), "Impact of FDI on GDP: A Comparative Study of China and India" observed that $1 \%$ increase in FDI would result in $0.07 \%$ increase in GDP of China and $0.02 \%$ increase in GDP of India.

Saini A., Law S. H., Ahmad A. H. (2010), "FDI and economic growth: New evidence on the role of financial markets" observed that the positive impact of FDI on growth "kicks in" only after financial market development exceeds a threshold level. Until then, the benefit of FDI is non-existent.

Chee Y. L., Nair M. (2010), "The Impact of FDI and Financial Sector Development on Economic Growth: Empirical Evidence from Asia and Oceania" observed that financial sector development enhances the contribution of FDI on economic growth in the region.

\section{RESEARCH METHODOLOGY}

Methodology describes the research route to be followed, the instruments to be used, universe and sample of the study for the data to be collected, the tools of analysis used and pattern of deducing conclusions. This research is conceptual \& descriptive in nature therefore the research study uses secondary data which has been collected out of the reviews of past research papers, national journals and other reports. The present study was carried out keeping the objectives in mind to explore the relationship between the inflows of FDI and its impact on Indian Economy.

\section{DATA ANALYSIS \& INTERPRETATIONS}

Figure1: FDI as percentage of GDP

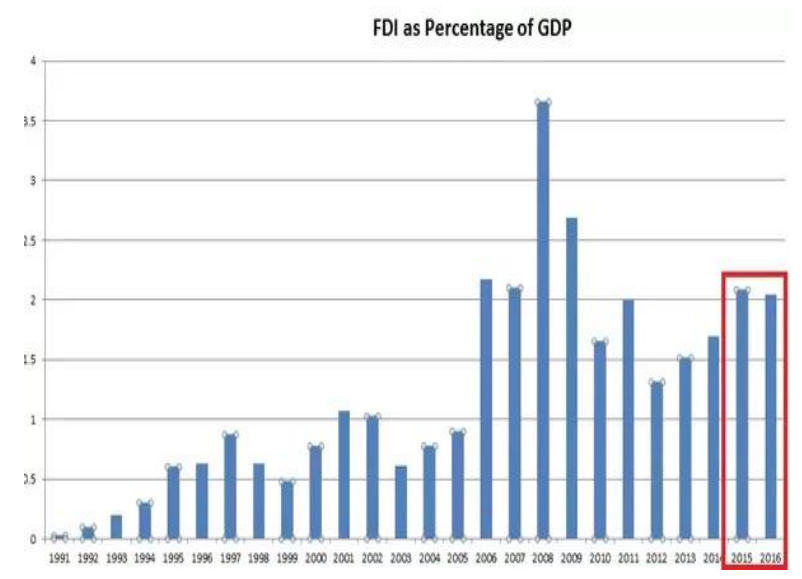

Source ( Bandopadhyay, 2017)

The above graph show that highest FDI was observed under 2008 for India which was quit safe due to its conservative funding stategies rather than aggressive policy making. In the year $2015 \& 2016$, the FDI over the percentage of GDP was observed above $2 \%$ but looking upto the whole scenario, the best phase of FDI in India was the era between $2006 \& 2009$. The red box area indicates the period of Make in India where FDI as percentage of GDP has shown a remarcable increase of $2 \%$ and has a sustainable growth. 


\section{Available online at www.ijrat.org}

(Figure 2: FDI Annual Percentage Change)

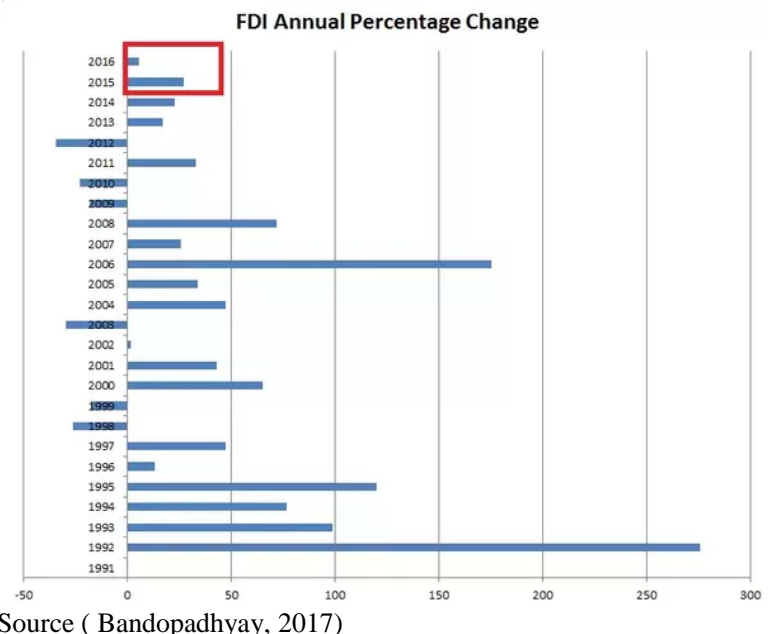

- Before India's economic liberalization in 1991, there were no FDI in India, so there was a sudden highs in the investment from foreign land in the year of 1992.

- Due to Asian financial crises in 1997, FDI falls down $\&$ showed negative trend.

- Again a dot corn crash in year 2002 and there was a reverse trend in year 2003.

- The global financial crisis in year 2008 was responsible for a low FDI in year 2009.

- Major fall in India's own currency led to the falling of FDI in 2012.

- Area under red box indicates the period of Make of India where India has been performing consistently globally. 2015 \& 2016 shows stable growth in FDI which is a prospect sign for the country.

The above figures shows that Make in India is growing eventually but these few years is just not enough to comment on the impact of FDI due to Make in India policy.

(Figure 3: India's sector wise investment classification)

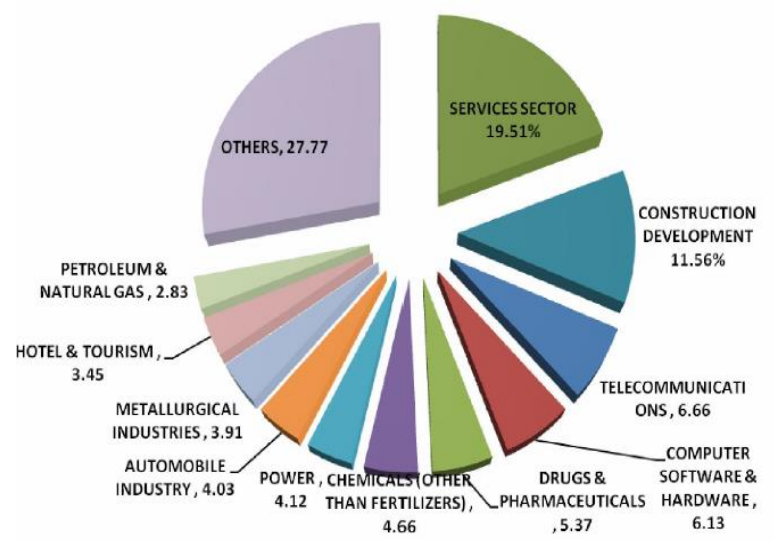

(Source: Singh, 2014)

From the above figure, it is clear that highest $19.51 \%$ of FDI in India is found in Service sectors, $11.56 \%$ in Construction development, $6.66 \%$ in Telecommunication, $6.13 \%$ Computer Software and hardware, $5.37 \%$ in Drugs and Pharmaceuticals, $4.66 \%$ in Chemical (other than fertilizers), $4.12 \%$ in Power, $4.03 \%$ in Automobile industry, $3.45 \%$ in Hotel and Tourism, $2.83 \%$ Petroleum and natural gas.

\section{SOURCES OF FDI}

Looking upto the graph, it is easily visible that highest FDI comes from Singapore during the year 2015-16 with a total investment of $\$ 13.69$ billion. But, during the year 2014-15, Mauritius \& USA showed total FDI investment of $\$ 8.35$ billion \& $\$ 4.19$ billion respectively.

(Figure 4: India's sector wise investment classification)

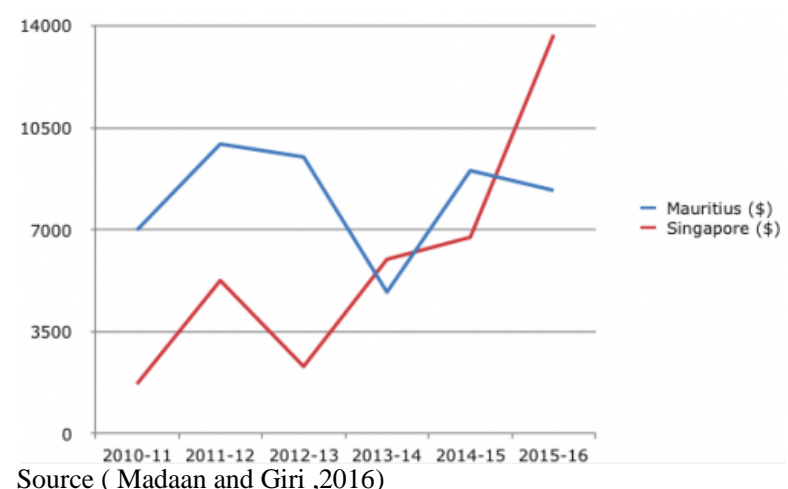

Source (Madaan and Giri ,2016)

\section{FINDINGS}

- After the launch of Make in India, the trends of FDI has shown positive influence over the foreign investors due to investor friendly signals received from India.

- India has jumped from $15^{\text {th }}$ position in 2014 to $10^{\text {th }}$ position in 2015 in the most trusted nations for FDI. 


\section{Available online at www.ijrat.org}

- India has managed to receive $\$ 40$ billion foreign investment during 2015-16 which is more than $30 \%$ from the previous year. (UNCTAD, 2016).

- Singapore has the highest FDI in India during the year 2015-16.

- Financial crises results in the withdrawal of FDI for that specific time period.

- India has the largest FDI in service sectors by $19.51 \%$ of total FDI.

- FDI are attracted towards Construction Development by $11.56 \%$.

\section{CONCLUSION AND SUGGESTIONS}

The study showed that the fastest growing service sector are transport, tourism, health and communication which are the top most pick for the foreign investors. The study also shows that the highest foreign investment in India during 2015-16 was from Singapore. The study also shows that Inward FDI gives long term benefits to the investing firm by enjoying the surplus profit generation and helps in overcoming the socio- economic problems of hosting nations like unemployment by generating employment opportunities in local economy. It eradicates technological backward problem through technological transfer. It allows to access in the global market platform for the firms and evolve better product through increase in market competition.

Thus, it was concluded that FDI contributes in stimulating the economic growth and development of our country. FDI has invested largely to the service sectors of India. There has been a positive impact of Make in India Policy towards FDI in India. It also reduces brain-drain from the host countries and provides to work for better market with upgraded techniques and handsome revenue generation. According to United Nations Conference in Trade and Development(UNCTAD), India managed $10^{\text {th }}$ position across the world to be the largest recipients of FDI with $\$ 44$ billion foreign investments.

\section{REFERENCES}

[1] Agarwal G., Khan M. A. (2011), "Impact of FDI on GDP: A Comparative Study of China and India", International Journal of Business \& Management, Vol. 6, No.10, pp- 71-79.

[2] Singh S., Singh M. (2011), "Trends and prospects of FDI in India", Economic Affair," Vol. 56, issue 1.

[3] Saini A., Law S. H., Ahmad A. H. (2010), "FDI and economic growth: New evidence on the role of financial markets", Vol. 107, issue 2, pp- 211213.
[4] Iyare Sunday O, Bhaumik Pradip K, Banik Arindam (2004), "Explaining FDI Inflows to India, China and the Caribbean: An Extended Neighborhood Approach", JSTOR, Economic \& Political Weekly, Vol. 39, No. 30, pp-3398- 3407.

[5] John Andreas (2004) in his work "The Effects of FDI Inflows on Host Country Economic Growth," pp 1-26.

[6] Chee Y. L., Nair M. (2010), "The Impact of FDI and Financial Sector Development on Economic Growth: Empirical Evidence from Asia and Oceania" International Journal of Economic \& Finance, Vol. 2, No. 2, pp-1-13.

[7] Bandyopadhyay K (2017), M.sc Economics, "What are the FDI trends in India before and after the Make in India."

[8] Singh G. Paul J., (2014), "Foreign Direct Investment in India- Trends, Pattern and Linkages", Journal of Business Management Studies, Vol. 10. No.1, pp- 19-29.

[9] Maddan H., Giri I.," (2016) Trends of Foreign Direct Investments in India." 